\title{
Absence of port-site metastases following staging laparoscopy for gastric carcinoma
}

\author{
M. L. Deogracias, J. C. Rodríguez-Sanjuán, F. de la Torre, R. A. García, M. S. Trugeda, \\ A. Domínguez and M. Gómez-Fleitas \\ General an Gastrointestinal Unit II. Hospital Universitario Marqués de Valdecilla. Santander, Spain
}

\begin{abstract}
Background: port-site metastases (PSM) have been reported following oncological laparoscopic surgery. However, their frequency after laparoscopic examination in gastric cancer has not been well established.

Material and methods: prospective follow-up of 41 patients having had a staging laparoscopy and a follow-up longer than 12 months. Mean age was 65 years (29-89). After staging, an open gastrectomy was performed in 33 cases. Mean follow-up was 21.4 (12-66) months. PSM was defined as a node in the former portsite wound with adenocarcinoma histology at biopsy.

Results: no patient showed clinical signs of PSM or port-site recurrence, even in advanced stages. We had no morbidity or postoperative mortality attributable to laparoscopic manoeuvres, and no need for laparotomy in cases without a gastrectomy indication.

Conclusions: our results suggest that staging laparoscopy is a safe procedure in gastric carcinoma, as it is not associated with PSM after even considerable follow-up, and has a very low complication rate.
\end{abstract}

Key words: Staging laparoscopy. Gastric cancer. Port-site metastasis.

Deogracias ML, Rodríguez-Sanjuán JC, de la Torre F, García RA, Trugeda MS, Domínguez A, Gómez-Fleitas M. Absence of port-site metastases following staging laparoscopy for gastric carcinoma. Rev Esp Enferm Dig 2006; 98: 755-759.

Recibido: 14-03-06.

Aceptado: 28-06-06.

Correspondencia: Maite López Deogracias. Unidad de Cirugía General y del Aparato Digestivo II. Hospital Universitario Marqués de Valdecilla. Avda. Valdecilla, s/n. 39008 Santander. e-mail: lopezdeogracias@mixmail.com

\section{INTRODUCTION}

Laparoscopy as a tumor staging procedure is increasingly used for gastric carcinoma (1-6). Port-site metastases (PSM) have been reported, however, following laparoscopic surgery in patients with cancer of the uterus (7), ovary (8), colon (9-11), gallbladder (12), pancreas, esophagus (6), kidney (13) or prostatic gland (14), a fact that raises some concern about the safety of laparoscopic surgery for malignancies. Other works, on the contrary, have found low port-site metastasis rates (15). As a result, studies have been addressed concerning the influence of laparoscopy on tumor spreading and patient survival. They suggest a role for $\mathrm{CO}_{2}$ diffusion (16-22), limited surgeon experience and consequent tumor handling $(21,23)$, direct cell adhesion to ports (24), trocar material composition (25), and hematogenous spread $(26,27)$. At present controversy persists.

Only anecdotal cases of patients having a gastric carcinoma -with peritoneal spreading- and PSM have been published. Also, there are few papers reporting an absence of such PSM, one with virtually no follow-up (2) and one monitored for more than 5 years (28). We report our experience with the laparoscopic staging of gastric carcinomas with the aim of assessing the PSM rate.

\section{MATERIAL AND METHODS}

The clinical data of patients operated on for gastric carcinoma in the Esophageal-Gastric Unit of University "Hospital Marqués de Valdecilla", Santander, Spain, are prospectively included in a database. We report the data from 41 patients having had a staging laparoscopy and a follow-up longer than 12 months. Mean age was 65 years (29-89). The staging laparoscopic technique was as follows: under general anesthesia three $10-\mathrm{mm}$ trocars were placed with no special protective measure in the umbili- 
cus (Hasson's trocar), right upper quadrant, and left upper quadrant, respectively. Using a 30-degree laparoscope the primary tumor was assessed, including an exploration of the lesser sac, and the spread to peritoneal surfaces or the liver as well. The patient is put in reverse Trendelenburg position to assess Douglas' cul-de-sac. A cytology sampling was obtained, which did not influence therapeutic decisions. Mean exploration time was 22 minutes (15-31). If the tumor was considered curable, the trocars were withdrawn and a laparotomy and radical gastrectomy were performed. In incurable cases the trocars were withdrawn and the procedure finished.

The classification according to pathological stages is shown in table I. Open gastrectomy was performed for 36 patients after staging laparoscopy. The remaining 5 patients were not classified as their tumors were not resected because of distant metastases.

\begin{tabular}{lcccc}
\multicolumn{5}{c}{ Table I } \\
\hline 1 & $I I$ & $I I I$ & $N$ & Not resected \\
\hline $42.5 \%$ & $17.5 \%$ & $20 \%$ & $10 \%$ & $12 \%$ \\
\hline
\end{tabular}

Follow-up consisted of interview, physical exam, and CEA measurement every three months, with abdominal computed tomography scanning in case of abnormal data and a yearly gastroscopy. PSM was defined as a node in the former port-site wound with histology of adenocarcinoma in biopsy samples. Mean follow-up was 21.4 (1266) months. Forty-one patients survived at least one year. Of these, $21(51 \%)$ were followed up for 1 to 2 years, 10 (25\%) for 2 to 3 years, 4 (10\%) for 3 to 4 years, 5 $(12.5 \%)$ for 4 to 5 years, and one patient for more than 5 years (66 months).

The statistical analysis was made using a KaplanMeier curve. Results are listed in figure 1.

\section{RESULTS}

During follow-up no patient showed clinical signs of PSM or port-site recurrent carcinoma with a follow-up of 1 year at least and 5 years at most, even in advanced stages. Nine patients died because of tumor progression, 5 are alive with locoregional recurrence or distant metastatic disease, and currently 27 patients survive and are clinically tumor-free. The survival curve is shown in figure 1 . We had no morbidity or postoperative mortality attributable to laparoscopic maneuvers, and needed no laparotomy for cases without a gastrectomy indication.

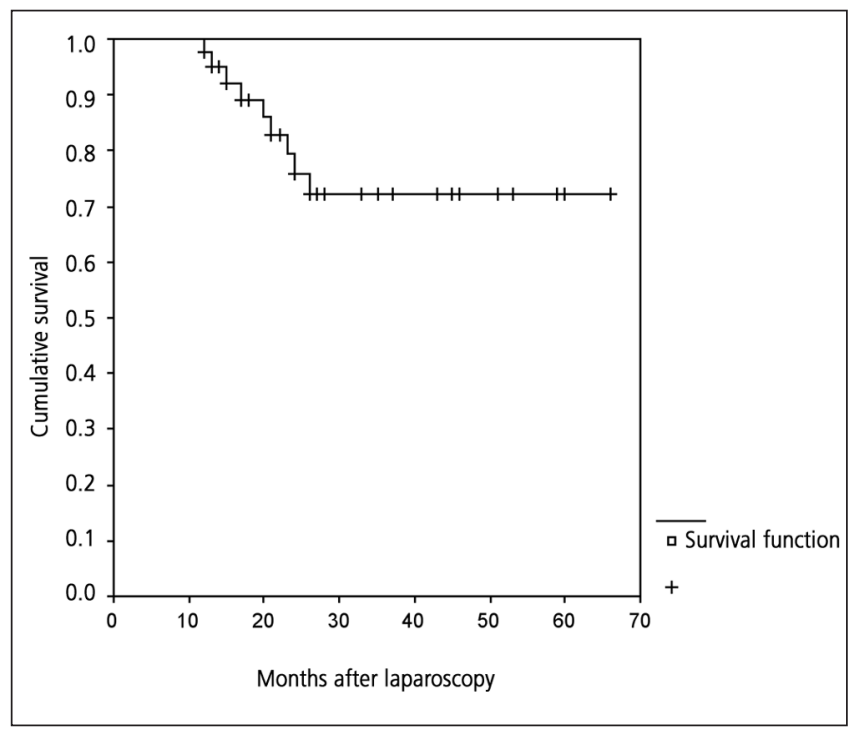

Fig. 1.

\section{DISCUSSION}

PSM have been related to $\mathrm{CO}_{2}$ insufflation and its metabolic and immunosuppressive effects, as well as to metallic ports (21), hematogenous spread, tumor cell aerosolization, and electrostatic adhesion of tumor cells (21). Of note, the excision of port sites in rats increased the likelihood of PSM in an experimental model (WATSON). Other investigators have applied some preventive measures, including peritoneal irrigation with povidoneiodine solution, in a murine model, as well as port-site protection with bio-reabsorbable materials $(27,29,30)$. However, none could establish a firm relationship between laparoscopy and increased or decreased PSM frequency.

Staging laparoscopy is increasingly used for abdominal tumors, especially for gastric carcinoma, as fairly common understaging by radiological methods may lead to non-therapeutic laparotomies. In addition to the avoidance of unnecessary laparotomies, staging laparoscopy can select candidates for neoadjuvant chemotherapy or chemo-radiotherapy, should such therapy be available and indicated. The procedure is well tolerated, even by elderly patients, and is associated with a low rate of complications. It is also possible to perform palliative procedures, and even radical gastrectomies through a laparoscope $(31,32)$, even though any such advantages would be cancelled out should PSM frequency be significant, as cases with a high probability of cure could recur at the port site. Tumors with a higher PSM rate include ovary, Fallopian tube, endometrium, uterine cervix, breast, and colon cancer, with all these rates being lower than $1 \%$ (this percentage varies among studies) (33). Most PSM are related to laparoscopic resection because of tumor manipulation. A lower PSM rate would be expected for 
only staging laparoscopy, but not many papers focus on this issue. There is one reported case of PSM after the staging laparoscopy of a stage-IVB gastric carcinoma (34). Another paper reported no cases of PSM, but follow-up was short. Our results suggest that staging laparoscopy is a safe procedure for gastric carcinoma as it is not associated with PSM after a considerable followup, and has a very low complication rate.

\section{REFERENCES}

1. Asencio F, Aguilo J, Salvador JL, Villar A, de la Morena E, Ahamad Escrig J, et al. Video-laparoscopic staging of gastric cancer. A prospective multicenter comparison with noninvasive techniques. Surg Endosc 1997; 11: 1153-8.

2. Abdalla EK, Pisters PWT. Staging and preoperative evaluation of upper gastrointestinal malignancies. Semin Oncol 2004; 31: 513-29.

3. Feussner H, Omote K, Fink U, Walker SJ, Siewert JR. Pretherapeutic laparoscopic staging in advanced gastric carcinoma. Endoscopy 1999; 31: 342-7.

4. Blackshaw GRJC, Barry JD, Edwards P, Allison MC, Thomas GV, Lewis WG. Laparoscopy significantly improves the perceived preoperative stage of gastric cancer. Gastric Cancer 2003; 6: 225-9.

5. Curte MJ. Port site metastasis. Am J Surg 2004; 187: 705-12.

6. Denzer U, Hoffman S, Helmreich-Becker I, Kauczor HU, Thelen M, Kanzler S, et al. Minilaparoscopy in the diagnosis of peritoneal tumour spread. Surg Endosc 2004; 18: 1067-70.

7. Sanjuán A, Hernández S, Pahisa J, Ayuso JR, Torné A, Martínez Román $\mathrm{S}$, et al. Port-site metastasis after laparoscopic surgery for endometrial carcinoma: Two case reports. Gynecol Oncol 2005; 96: 53942.

8. Morice P, Viala J, Pautier P, L'homme C, Duvillard P, Castaigne D. Port-site metastasis after laparoscopic surgery for gynaecological cancer. A report of six cases. J Reprod Med Oct; 2000; 45: 837-40.

9. Kokckerling F, Reymond MA, Schneider C, Hohenberg W. Errors and risks in oncologic laparoscopic surgery. Chirurg 1997; 68: 21524.

10. Lacy AM, Delgado S, García-Valdecasas JC, Castells A, Pique JM, Grande L, et al. Port site metastasis and recurrence after laparoscopic colectomy: A randomised trial. Surg Endosc 1998; 12: 1039-42.

11. Kosugi C, Ono M, Saito N, Sugito M, Ito M, Murakami K, et al. Port site recurrence diagnosed by positron emission tomography after laparoscopic surgery for colon cancer. Hepatogastroenterol 2005; 52: 1440-3.

12. Giuliante F, Ardito F, Vellone M, Clemente G, Nuzzo G. Port-sites excision for gallbladder cancer incidentally found after laparoscopic cholecystectomy. Am J Surg 2006; 191: 114-6.

13. Dhobada S, Patankar S, Gorde V. Case report: Port-site metastasis after laparoscopic radical nephrectomy for renal cell carcinoma. J Endourol 2006; 20: 119-22; discussion 122.

14. Larousse C, Brasseur P, Sukkarieh F. Port-site metastasis following laparoscopic prostatectomy for mucinous adenocarcinoma of the prostate. J Radiol 2005; 86: 337-9.

15. Childers JM, Aqua KA, Surwit EA, Hallum AV, Hatch KD. Abdominal-wall tumor implantation after laparoscopy for malignant conditions. Obstet Gynecol 1994; 84: 765-9.

16. Lee SW, Gleason NR, Bessler M, Whelan RL. Abdominal wound tu- mor recurrence after open and laparoscopic-assisted splenectomy in a murine model. Dis Colon Rectum 1998; 41: 824-31.

17. Mathew G, Watson DI, Ellis T, De Young N, Rofe AM, Jamieson GG. The effect of laparoscopy on the movement of tumor cells and metastasis to surgical wounds. Surg Endosc 1997; 11: 1163-6.

18. Watson DI, Ellis T, Leeder PC, Neuhaus SJ, Dodd T, Jamieson GG. Excision of laparoscopic port-sites increases the likelihood of wound metastases in an experimental model. Surg Endosc 2003; 17: 83-5 (Epub 2002 Sep. 30).

19. Watson DI, Mathew G, Ellis T, Baigrie CF, Rofe AM, Jamieson GG. Gasless laparoscopy may reduce the risk of port-site metastases following laparoscopic tumour surgery. Arch Surg 1997; 132: 166-9.

20. Hirabayashi Y, Yamaguchi K, Shiraishi N, Adachi Y, Saiki I, Kitano $\mathrm{S}$. Port-site metastasis after $\mathrm{CO} 2$ pneumoperitoneum. Surg Endosc 2004; 18: 1113-7.

21. Lee SW, Gleason NR, Bessler M, Whelan RL. Port-site tumor recurrence rates in a murine model of laparoscopic splenectomy decreased with increases experience. Surg Endosc 2000; 14: 805-11.

22. Gammal EM, Szabo G, Nagy P, Brath E, Peto K, Olah A, et al. The role of pneumoperitoneum and the "chimney effect" on the development of port site metastasis. A new experimental animal model using Furka's spleen tissue suspension. Magy Seb 2005; 58: 89-92.

23. Young-Fadok T, Talac R, Nelson H. Laparoscopic colectomy for cancer; The need for trials. Semin Colon Rectal Surg 1999; 19: 94-101.

24. Whelan RL, Sellers GJ, Allendorf JD, Laird D, Bessler MD. Trocar site recurrence is unlikely to result from aerosolization of tumor cells. Dis Colon Rectum 1996; 39: S7-13.

25. Brundell S, Tucker K, Chatterton B, Hewett PJ. Experimental study of the material composition of laparoscopic ports on tumor cell adherence. Br J Surg 2002; 89: 928-32.

26. Brundell S, Ellis T, Dodd T, Watson DI, Hewett PJ. Hematogenous spread as a mechanism for the generation of abdominal wound metastasis following laparoscopy. Surg Endosc 2002; 16: 292-5 (Epub 2001 Nov. 12).

27. Ramírez PT, Wolf JK, Levenback C. Laparoscopic port-site metastasis: Etiology and prevention. Gynecol Oncol 2003; 91: 179-89.

28. Ribeiro U Jr, Gama-Rodrígues JJ, Safatle-Ribeiro AV, Bitelman B, Ferreira MB, Laudanna AA, et al. Prognostic significance of intraperitoneal free cancer cells obtained by laparoscopic peritoneal lavage in patients with gastric cancer. J Gastrointest Surg 1998; 2: 244-9.

29. Sasaki T, Shimura H, Tanaka T, Nakashima K, Matsuo K, Ikeda S. Protection of trocar sites from gallbladder cancer implantation by sodium hyaluronidate shill carboxymethylcellulose-based bioresorbable membrane (Seprafilm) in a murine model. Surg Endosc 2004; 18: 246-51.

30. Ribeiro U Jr, Gama-Rodrigues JJ, Safatle-Ribeiro AV, Bitelman B, Ibrahim RE, Ferreira MB, et al. Prognostic significance of intraperitoneal free cancer cells obtained by laparoscopic peritoneal lavage in patients with gastric cancer. J Gastrointest Surg 1998; 2: 244-9.

31. Palman L. The problem of port-site metastases after laparoscopic cancer surgery. Ann Med 1997; 29: 447-81.

32. Kitano S, Shiraishi N. Current status of laparoscopic gastrectomy for cancer in Japan. Surg Endosc 2004; 18: 182-5.

33. Lee SW, Gleason NR, Bessler M, Whelan RL. Peritoneal irrigation with povidone-iodine solution after laparoscopic-assisted splenectomy significantly decreases port tumor recurrence in a murine model. Dis Colon Rectum 1999; 42: 319-26.

34. Mc Culloch P, Johnson M, Jairam R, Fischer W. Laparoscopic staging of gastric cancer is safe and affects treatment strategy. Ann R Coll Surg Engl 1998; 80: 400-2. 